\title{
IT Role in Fulfillment of Profit \& Loss Sharing (PLS) Mechanism
}

\author{
Bijan Bidabad \\ B.A., M.Sc., Ph.D., Post-Doc. \\ Professor \\ Economics and Chief Islamic Banking Advisor \\ Bank Melli, Iran \\ E-mail:bijan@bidabad.com \\ Mahmoud Allahyarifard \\ Expert of R\&D Department \\ Bank Melli Iran \\ E-mail:allahyarifard@gmail.com
}

\begin{abstract}
In this paper, we are going to introduce a new IT master solution to improve non-usury banking performance. All divine religions emphasize on usury prohibition. It is concluded that with some IT solutions, it may be possible to fulfill the worldly requirement by use of IT systems without any incredulity. Since depositors are shareholders of Non-Usury Bank Corporation (NU Bank Co), therefore integrated information systems can provide suitable infrastructure for transactions recording and management done by all participants' chains; and the end of process the yields of investment capital of depositors that invest in real economy can be distributed by safe delivery channels such as branches, ATM, WEB, Meaningful WEB. IT (as BPR, ERP, CRM, SCM, MES, MEX, HRM, WFM) that use single and integrated data warehouses) accompanying with standardization in all processes not only prepare PLS mechanism as main difference between conventional and non-usury banking but also simplify risk management and decline operational risk in comparison with conventional non-usury banking. Foundation of real non-usury banking can be based on an integrated IT system that links depositors, NU Bank Co, business partners, investors, stock exchange agencies, social security organization, certificate authorities (CA). Therefore, all related sectors may access the working flow of capital; IT processes, investment returns, and this causes stability in financial markets and achieve social justice establishment. In this paper, we are going to find a solution to this question: is it possible to connect depositors, bank, and investors in an integrated IT system to bring out PLS mechanism? Accordingly, we use a new kind of bank named by "Non-Usury Bank Corporation ( $\mathrm{Nu}$ bank Co)" to fulfill the PLS criterion. This kind of non-usury bank will be capable of being established in different commercial law systems around the world. Thus, it will provide a suitable environment to automate non-usury banking operations that connect profits of depositors, bank, and loaners all together by using financial automatic communication channels.
\end{abstract}

Keywords: PLS, Islamic banking, finance, usury, Information technology.

\section{Introduction}

In divine books such as Quran, Torah, and Bible, the prohibition of usury has been explicitly declared. However, there are many differences in the definition of usuric financial operations in comparison with non-usuric operations. Bidabad and Harsini (2003) ${ }^{\mathrm{I}}$ by scrutinizing usury definition and using theosophy principal of jurisprudence defined some criteria to distinguish usuric from non-usuric transactions. It seems that these criteria may be accepted as an ending point of usury definition. The criteria are:

\footnotetext{
I Bidabad, B. Harsini, A. (2003), Religious-economic analysis of usury in consumption and investment loans and shortages of contemporary jurisprudence in finding the rules of religion legislator. Monetary and Banking Research Academy, Central Bank of Iran, 2003, (in Farsi).

http://www.geocities.com/bijan_bidabad/reba7.htm
} 


\section{Loaner must share in profit/loss of the economic activity of loanee. \\ 2. The rate of interest must not be determined and conditioned before. \\ 3. Interest in consumption loans is usury. \\ 4. Foreign currency exchange (without interest) is not usury.}

If we accept the above criteria for non-usuric banking operations, then we may use IT systems as an important standpoint to optimize efficiency and effectiveness of this type of banking. Otherwise, there are operational ambiguities for implementing the PLS procedure.

Since in «Non-Usury Bank Corporation» (NU Bank Co) ${ }^{1}$ depositors are stakeholders. Therefore investment return should be distributed among them proportionally based on the amount of their own deposits. The most important factor causing ineffectiveness of conventional non-usuric banking to achieve PLS mechanism is the inability to distribute bank's profit at the end of the financial period. On the other hand, the incapability of conventional non-usuric banking to achieve PLS mechanism comes from disconnectivity of profit and loss accounting systems and real economic returns of economic activities. Thus, this causes some ambiguities in nonusuric nature of transactions. Generally, the main preventing factors to PLS fulfillment are as follows:

- There isn't systematic connection among depositors (as a supplier of financial resources or as bank's stakeholders) and loaner (as real investors or bank's business partners)

- Impossibility of creating a specific portfolio for each depositor; and precise accounting of her yields by conventional traditional or semi-automatic systems.

- Existence of different profit (interest) rates for different term deposits based on their progressive time durations returns is a source of fluctuations in financial markets and causes unfair distribution of deposit holders returns. Since the differential deposit interest rates are not equal to the real economy rate of return; thus, it will be contradictory with PLS mechanism.

- The multiplicity of loan's interest rates and deposit's interest rates and their discrimination from the real economy rate of return causes the unfair distribution of profit coming from financial activities and is contradictory with PLS mechanism.

- In order to fulfill of PLS mechanism bank's stakeholders should be the bank's depositors, and therefore bank instead of maximizing shareholder's profit should maximize depositors' profit.

\section{Conventional non-usuric banking role in financial markets}

Bidabad and Harsini (2003) by using mathematical modeling, proved that financial intermediaries, as an independent sector of the economy is a source of fluctuations in interest rates and will fluctuate real markets. The term structure of loans' contractions and lags of interest rates fluctuations will cause in-coordination between financial resources supply and demand and therefore will cause permanent fluctuations of financial markets. Regarding the possibility of using PLS mechanism as a solution to prevent real economy oscillation coming from financial markets; what would be the solution to new non-usury banking architecture? We will try to answer this question in this paper.

Banks as economic firms are active in two markets. On the one hand, they demand financial resources from depositors (in deposit resources market), and on the other side, they supply credit to investors (in the credit market). As Bidabad and Harsini (2003) have shown, conventional non-usuric banks do not act as financial intermediaries who receive a fraction of investment returns from two parties of contracts as charges. If banks did as intermediaries, then many of usuric juristic problems of conventional banks activities would be eliminated. Conventional non-usuric banks act as economic firms and maximize their profits or minimize their interest and non-interest costs, which the same markup price of resources mobilization.

$$
\operatorname{Max}: \pi=\sum_{i}^{n} R_{i}\left(r_{i}^{L}\right)-\sum_{j}^{m} D_{j}\left(r_{j}^{D}\right)+\sum_{k}^{o} T R_{k}-\sum_{l}^{p} T C_{l}
$$

$\pi$ : Profit of bank.

$\mathrm{R}_{\mathrm{i}}$ : Revenue of credit supply to investors in different contracts with $r_{i}^{L}$ loan interest rate.

$\mathrm{D}_{j:}$ Profit payment to deposit holders for deposit type $\mathrm{j}$ with $r_{j}^{D}$ deposits interest rate.

$\mathrm{TR}_{\mathrm{k}}$ : Revenue of offering banking services to customers.

$\mathrm{TC}_{1}$ : Total cost will be such as office, organizational, amortization, tax, personal

\footnotetext{
${ }^{\text {I }}$ B. Bidabad, (2005), Non-Usury Bank Corporation (NUBankCo) The Solution to Islamic Banking,
} 
Due to lack of IT penetration in operational, supervision and even managerial processes of conventional banks, the administration, personnel, and overhead costs are less flexible and effective. Therefore, assuming constant $\mathrm{TC}_{\mathrm{I}}$ and $\mathrm{TR}_{\mathrm{k}}$, the expression $\sum_{i}^{n} R_{i}\left(r_{i}^{L}\right)-\sum_{j}^{m} D_{j}\left(r_{j}^{D}\right)$ will maximize the profit. Just as shown, there is not a simultaneous and systematic relationship between $D_{j}$ and $R_{i}$. In other words, non-usuric banking, the banks' profit resulting from financial transactions made with depositor's resources should be distributed among depositors after deduction of operational costs ${ }^{\mathrm{I}}$. Two major problems are encountered to access this mechanism as follows:

- In conventional non-usuric banking, depositors are not the bank's shareholders. This fundamental problem can be solved by the application of a newly defined special banking system named by "Non-Usuric Bank Company (NUBankCo.)”. This bank is explained by Bidabad (2005).

- Profit (interest) distribution to depositors is due to a long delay of finalizing auditing processes after the end of the financial year. Whereas, it can be shortened by using IT systems. Thus the distribution of profit based on PLS mechanism can be done in shorter periods and more rapidly. On the other side, because of heavy overhead cost in conventional banking, endeavor to implement PLS mechanism would not be very successful. Thus IT and ICT systems could initiate new opportunities to implement real PLS mechanism. This also can reduce overhead cost in conventional banking.

3. Microlink Banking Solution (MIBS) and experiences relating to the supply of new non-usuric products MIBS is a new solution for banking activities by ICT master solutions. However, Microlink's activity domain is not restricted to non-usuric banking products. Microlink is working in an Islamic country and thus has focused on non-usuric banking products. Therefore, Microlink's experience will be useful for us to improve our idea in this paper.

MIBS provides a complete plan to meet the needs of global financial transactions. The system is based on conventional banking practices with the application of new technologies of information and communication and distribution channels as the internet. Reflexability, parametricity, and security of MIBS are of its characteristics. MIBS was designed and developed on a 3-tier architecture of client/server and Online Transaction Processing (OLTP). This architecture provides a smoothed distribution and concentrated online transactions with the loadbalancing capability and fast responding and low bandwidth requirement. MIBS is compatible with the Linux operating system and IBM-z series mainframe systems. MIBS covers Islamic banking products with multi-currency and multi-financial-institutions capabilities.

Figure I: System Overview of MiBS

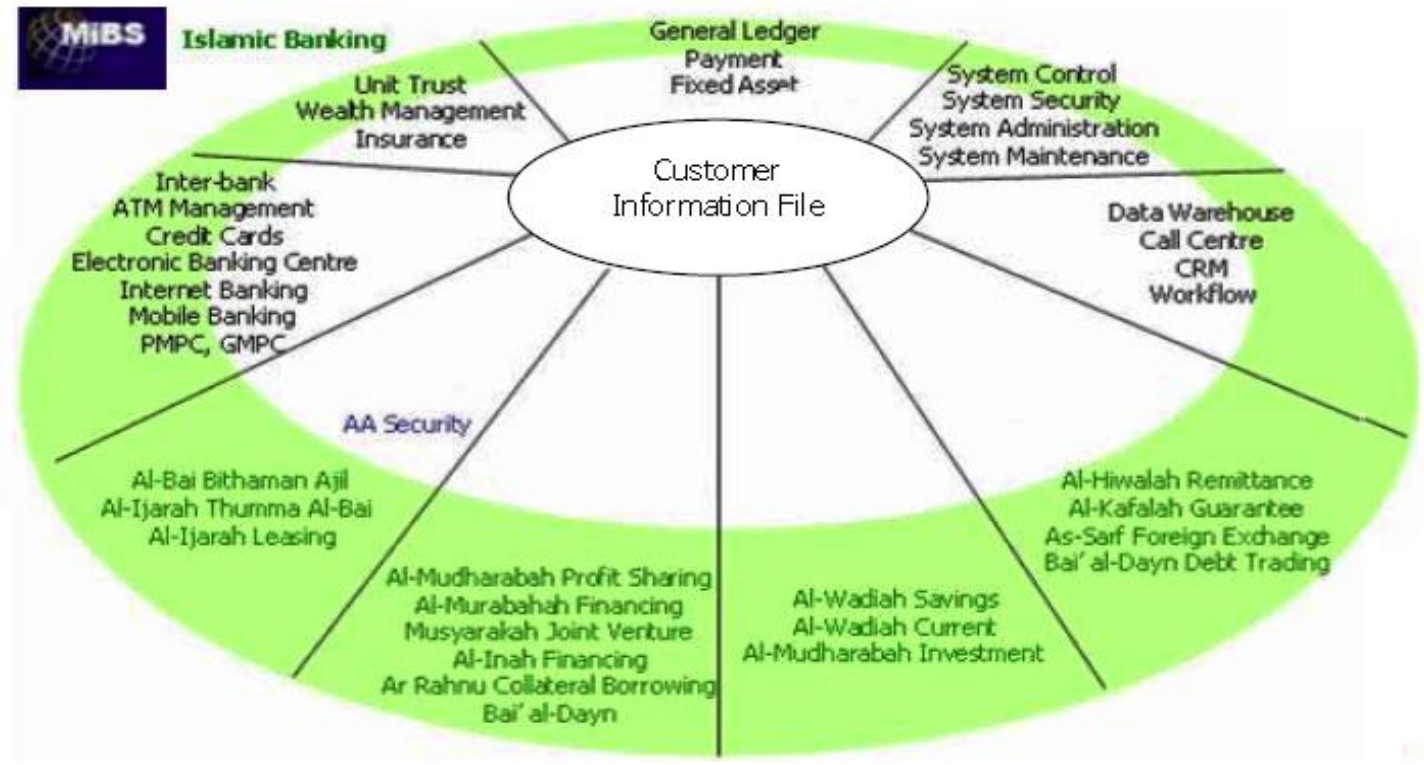

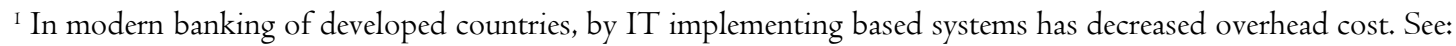
Allahyarifard, Mahmoud, "E-banking services and its operational requirement in comparison with operational cost of different banking services", Monetary and Banking Research Academy, Central Bank of Iran, 2005, (Farsi).
} 


\section{Customer Information File (MIBS/CIF)}

MIBS/CIF has a global approach regarding customer relationship with the financial institutions. In this system, a customer account is unique (i.e., in the master table, a primary key ${ }^{\mathrm{I}}$ is assigned to every customer). Therefore, all tiers and modules of system and databases and applications connect by this unique number. CIF features are as follows:

- Customers' linkages based on MIBS modules provide a comprehensive database of current and historical information of the customer.

- The capability of customers' link maintenance.

- Blacklisting of customers and related products to facilitate credit-processing checks.

- Capability to define customer's inquiry and their level of access and assigning user/group accessions permissions.

- Information search can be done by account number, identification card characteristics, employment categories, and other recorded indices.

- $\mathrm{AA}^{2}$ secure capability to protect customers' inquiries from intruders or unauthorized exposures.

- Interfaces with Data-Warehousing module on customer profitability analyses.

\section{Al-Wadiah Savings Account (MIBS/WSA)}

MIBS/WSA is an online system that collects and update all financial transactions in MIBS databases directly and preserve real-time information. WSA designed on a safe-custody base and distribution of profit among customers is according to PLS mechanism. MIBS/WSA features are as follow:

- This system, with other MIBS modules, uses systemic information resources participatory.

- Provides multiple users defining capability and their authentications with multi-currency products.

- Automatic payment system capability and salary payment system.

- Electronic fund transfer to other accounts and interactions with other systems using gateways.

- The capability of using passbooks and statements for different accounts type.

- Overdraft system capability based on a minimum of account's balance average and a number of transactions.

Al-Wadiah Current Account (MIBS/WCA): MIBS/WCA operates as a saving account. This production is managed by checkbook and contains the check-imaging system. This system can verify the account owner's signatures and contains blacklisted checking account holders.

Modaraba Investment (MIBS/MI): This production is an online time deposit and contains two types of fixed and short term deposits. This product is based on two contractions. The first one is the Islamic Modaraba, and the second is Al-Inah. In al- Modaraba contracts, rate of return is floated and is based on PLS mechanism, and in the second, rate of return is fixed.

Hire purchase financing (MIBS/AITAB): This production is conditional leasing for the purpose of buying. Al-Ijareh Leasing (MIBS/IL): This product contains all leasing financial facilities of "Full pay Out Lease", "Deposit Lease", "Residual Lease", and "Operating Lease".

Islamic Financing (MIBS/IF): This product by using other products of Beyea, Ijareh, Modarah, Morabaha, Mosharaka, and Kefala create other financial products.

Share Financing (MIBS/SF): It contains all operations on shares as tracing and unremitting, evaluating of shares, communication with stock-agencies, accounting of agency's commission and special reporting to shareholders and agencies, ....

Ar-Rahnu (MIBS/AR): It is an online system based on the Rahn contract. According to MIBS/AR in lieu of loan, the debtor should provide a valuable asset as collateral for the debt.

As a summary, what is known as MIBS, is just supplying IT-based products and services that can be seen in conventional e-banking. But, in comparison with non-usuric banking products and services, it is similar to traditional banking frameworks, and there are no significant differences regarding products and services. Therefore, there are many applicability problems and usury dubieties in MIBS.

\section{Non-usuric banking information systems architecture and fulfillment of PLS mechanism}

\footnotetext{
${ }^{\mathrm{I}}$ A primary key is a unique field in master table. In Relational Database Management Systems (RDBMS) all referential integrity is based on this fields.

${ }^{2} \mathrm{AA}$ is one of security ranking of system indexes
} 
In designing of modern non-usuric banking architecture similar to other IT-based businesses, using global standards, models, and factors are necessary. The related factors are fallow as:

- Infrastructures: Executive prosperity of modern non-usury banking depends upon suitable technical, telecommunication, cultural, educational, and legal infrastructures. In the case of asymmetric dis-coordination in infrastructural chains, e-banking will fail. E-money and e-payment systems and Real Time Gross Settlement system (RTGS) will be important factors in e-banking development and depend on the existence of authorities to certificate and proof digital signatures in a manner that authenticity, integrity, nonfabrication, and non-reputation of exchanged data be recognizable.

- Standardization: Before designing and implementing IT systems, it is necessary to define operational, supervisory, and managing standards. These standards should also be considered in information and communication management systems. These standards can be in the realm of architecture layers and applications programming with multi-lingual, multi-currencies, and accounting regulations supports. They should contain security standards in network communication layers: physical, data link, network, transport, session, presentation, application in the OSI model $^{\mathrm{I}}$. All of the standards are designed as compatible with globalization notions and directions.

Prohibition of usury principle in non-usuric banking causes international standards and supervising organizations on banking operations such as the Basel committee ${ }^{2}$ do not cover all of the non-usuric banking needs. Therefore, Islamic countries have been planning for establishing new organizations to standardize and codify uniform regulations for supervision on Islamic banking activities. Important organizations in this relation are the Accounting and Auditing Organization for Islamic Financial Institutions (AAOIFI) ${ }^{3}$ and The Islamic Financial Services Board (IFSB) 4 . Despite the performed endeavors to establish different organizations to motivate and

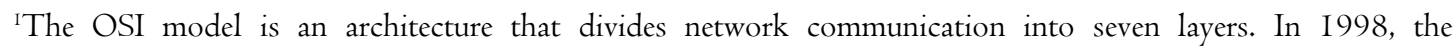
International Standards Organization (ISO) released a set of specifications that describes a network architecture for connecting dissimilar devices. TCP/IP protocols follow a four-layer conceptual model known as Department of Defense (DOD) model: Application, Transport, Internet, and Network Interface. In order to access details refer to Microsoft Windows 2000 Network Infrastructure Administration, Microsoft press ,2000, Washington

${ }^{2}$ Week capital situation of international banks in the beginning of 1980s and international disagreement on capital definitions and capital adequacy regulations caused the committee of banking regulations and supervision on banking operations of Bank for international settlement located in Basel city of Switzerland to issue regulations on international standards on capital adequacy measure. These standards introduced to active international banks of Group I0 countries (OECD members). In order to uniform the rules, Basel committee followed two main goals:

- The new rules will improve and strengthen the soundness and stability of international banking.

- Regulations become fairer, and application of regulations in banks of different countries be more compatible to minimize unequal competition of international banks.

Capital Adequacy Ratio (CAR) is a financial index for assessing banks and financial institutions and indicates the success or failure of these institutions in their risk management and financial activities. This ratio as a standard should not be less than $8 \%$. In 200I on the basis of new agreement under the Basel 2 this ratio was changed to calculate CAR so the credit and market risks entered into the CAR and operational risk entered into the dominator of the CAR's ratio in calculation of weighted value of assets. Therefore, comprehensive methods for risk recognizing introduced.

${ }^{3}$ Accounting and Auditing Organization for Islamic Financial Institutions (AAOIFI) was established in I99I by Islamic banks and has a board of directors including three central bank governors of Bahrain, Sudan and Jordan and its chairman is Bahrain's commerce deputy minister. The responsibility of AAOIFI is supervising and defining required regulations and standards for Islamic banking. AAOIFI has issued 43 standards and statements, which are mandatory in Bahrain, Sudan and Jordan at the first phase, and at the next phase Qatar and Saudi Arabia also adopted these regulations and majorities of countries also accepted these regulations as bases for their standards and regulations. Organization structure of AAOIFI consists of six parts of General Assembly, Board of Trustees, Accounting and Auditing Standards Board, Sharia Board, Executive Committee and General secretary. The Accounting and Auditing Standards Board is composed of fifteen part-time members assigned by the Board of Trustees for a four-year term. Members of the Standards Board are representatives of the following categories:

- Regulatory and supervisory authorities

- Islamic financial institutions

- Shari'a jurists

- Accounting and auditing professionals on Islamic financial institutions.

- Users of financial statements of Islamic financial institutions.

- University professors in accounting and financial fields.

4) The first step of defining prudential and supervisory regulations and standards for Islamic banking by Bahrain Monetary Agency (BMA) is the Islamic Financial Services Board (IFSB). This frame is named by 'Prudential Information \& Regulatory Framework for Islamic Banks (PIRI) and is based on guidelines of Bahrain AAOIFI and the Basle Committee on Banking Supervision. This committee is in Malaysia and representatives of central banks of Bahrain, 
develop non-usuric banking by different countries and international organizations such as world bank and IMF to standardize and deregulating non-usuric banking in globalization process; unfortunately, no executive achievement has been perceived in non-usuric banks. Thus Islamic countries instead of establishing different organizations and performing independent-isolated activities should establish a unique supervisory organization to codify regulations, standards, and protocols for all non-usuric banks and by implementing IT should provide globalization infrastructures for non-usuric banking.

- IT-based systems: IT systems in the master plan should be integrated, and inter-network or outer-network separated units should be avoided. New information systems architecture will be based on integrated management of IT and ICT, and all firm's systems use a unique data warehouse, or information database management is integrated and based on automatic interaction and transfer of information among databases. In this regard, it is necessary to implement database server as client/server, WEB applications, data center operating systems, and N-tier capability for systems. All information resources in inter-network and outernetwork will connect together and will create an IT master solution for implementing PLS mechanism. In this solution, IT subsystems are followed as:

- Business Process Reengineering (BPR): BPR is operational, supervisory, and management processes' reconsideration for producing new products or services and is similar to traditional markup reduction. BPR looks for strengthening higher value-added and eliminating low value-added processes. Application of IT and then BPR in the production of goods and services causes a decrease in overhead cost. Because in traditional business, BPR improve the processes, but a new generation of BPR in IT-based business causes structural upheaval in processes. In this regard, BPR tries to change and improve in-organization, and out-organization processes and all interacting firms should obey its guidelines. Thus, the role of standardization and supervisory organizations become important.

- Enterprise Resource Planning (ERP): ERP systems are designed to reduce overhead costs arising from the incompatibility of systems and prevent invalid and inconsistent information. Despite the similarity between ERP and Management Information System (MIS), there are differences among them. ERP systems embrace all information resources in inter-network or even in outer-network, and therefore information resources link together, but in MIS, integration of information resources are limited to inter-network or even limited to some segments of an enterprise.

- Customer Relationship Management (CRM): IT-based businesses are customer oriented as their most important goal. Delivery channels of electronic services as internet and intranet equipment could not fulfill all customers' needs, and dissatisfaction of customer may lead to fewer transactions and missing customer and finally reduction of enterprise's profit. This is a strong reason to use intelligent systems for customer relationship. Modern CRM systems are overshadowed new technology of Meaningful WEB ${ }^{\mathrm{I}}$ which response to the customer automatically and even will assess the willingness of customers after delivery of goods or services.

- Supply Chain Management (SCM): Since some of the transactions occur between banks and suppliers, therefore the SCM system covers all connection processes among them.

- Manufacturer Executive Systems (MES): This system is installed and added as a class or module to ERP systems and interacts between the executive layer of producer enterprises as counterpart or investment partner and bank. This system will cover all production processes.

- Human Resource Management (HRM): One of the necessary systems for modern non-usuric banking is HRM. Since human resource has an important role in enterprise development, therefore implement of strength and updated database of employees information is a necessity. This system should contain interactive and online capabilities of economic, training, educational and cultural, favorites, and hobby/entertainment needs of employees. Knowledge-based businesses are based on Knowledge-worker and thus determining the quality of the organization as Knowledge-mapping and Knowledge-management are

Malaysia, Sudan, Jordan, Indonesia, Kuwait, Iran and Saudi Arabia and IMF, IDB and AAOIFI met at the IMF offices in Paris and signed an agreement on a draft for establishment of the IFSB (Islamic Financial Services Board). The objectives of PIRI establishment cover six main areas including capital adequacy, asset quality, management of investment accounts, revenue quality, liquidity and corporate governance. See: "Banking Monetary Agency Issues New Islamic Banking Regulations", Vol.XLV No.5, 4 February 2002.

I Meaningful Web is a new version of World Wide Web (WWW) that could process keywords by webs or search engines. 
possible through HRM. In this system, all correspondences among personnel and managers are done digitally, and personnel registers their different needs through the system.

- Workflow Management (WFM): WFM determines the principles of process and tracing management of messages and information. Thus, it provides a distinctive capability of the participant. It is possible to determine the participant's roles and suitable principles for tracing of messages, transactions, and information among participants and databases. In new non-usuric banking by the WFM system, we can trace the physical and financial progress of investment projects based on Mosharka and Modaraba contracts. It is expected that integrating trend of internal WFM systems with external E-commerce systems because of the size-reduction of business enterprises and increasing their efficiency will develop. The imposition of applying Electronic Data Interchange (EDI) by business partners and loaner (investors) in the new non-usuric bank is an important requirement of the system architecture and WFM will play an effective role in this system.

- Delivery Channels: Delivery channels of new non-usuric banking are resembled other modern banking systems and include branches, phone, ATM, POS, WEB and mobile devices, such as mobile phone. Distribution channels should be designed consistent with technical, telecommunications, cultural, educational, and legal infrastructures.

- External Interface/Gateway: To receive real information about Mosharaka and modaraba contracts, system compatibility, and gateway capability for data broadcasting and information interchange with other information systems are necessary.

- Risk Management: Implement of non-usuric banking contracts such as Mosharaka and Modaraba without using IT-based systems will increase risks in comparison with conventional banking. Despite transferring a fraction of credit risk to depositors as stakeholders of investment activities, however, increase in supervisory and operational process on Mosharaka and even Modaraba contracts will cause specific risks in non-usuric banking because of the following reasons:

- Permanent auditing and supervision on joint ventures investments for getting confidence regarding enterprise/investment management is of PLS necessities.

- Non-uniform shapes and practices of Mosharekeh and Modaraba contracts.

- Inexistence of valid and updated information about joint venture investments or financing of Modaraba contracts to control Modareb and impossibility of surveying faults and mismanagement of Modareb before ending period of the contract are reasons for increasing operational risk in non-usuric banking in comparison with conventional banking.

Since the important characteristic of Mosharekeh contracts is PLS mechanism, therefore in order to decline the credit risk of these contracts, we can not link these type of contracts to collaterals or other guarantees. Thus operational risk management importance and reasons for auditing and supervising on Mosharekeh and Modaraba contracts are quite clear in non-usuric banking.

\section{Non-usury banking products and services}

Since IT based businesses are customer oriented, thus new non-usuric banking should supply usual or non-usual products and services to customers in general. The correctness of an action criterion will be the human intention and its nature whom wise rules should not be changed by reforming ${ }^{\mathrm{I}}$. Therefore, in new non-usury banking, every products and service could be supplied by the condition that it is not contaminated with usuric consequences. Conventional products and services in non-usuric banking may belong to the following categories:

- Depositories: Deposits include Gharz-al-Hasana or investment accounts.

- Loaning: Loans could be of consumption type without any excess with the exception of commission fees (Kind loan thereafter). Other loans for the purpose of value add production or investment activities, and they should confirm two criteria of profit and loss sharing and non-determinacy of surplus rate which it is the most fundamental criterion to distinguish usuric and non-usuric financial transactions ${ }^{2}$. Therefore the following loan/credit products may be used:

- Kind loan (non-interest loans for needy people and the non-usuric bank can receive only commission fees suitable with services offered and not more).

- Civil partnership (to participate in investment and investment return based on the share of each depositor).

- Legal partnership (to participate in financing other business partners and based on the share of each

${ }^{\text {I }}$ See Bidabad and Harsini (2003).

${ }^{2}$ See Bidabad and Harsini (2003). 
depositor).

- Direct investment.

- Modaraba (validity of this transactions is based on PLS mechanism, which will be accessed by IT-based systems-proposition of this paper).

- Forward transactions (access to products and services processes information of business partners at ecommunity will cause to determine the price of goods and services precisely in the maturity.

- Jo'aalah (in this contract loan are received in order to create value added. Thus, the profit is distributed as investment return share and commission fees).

- Mozara'a (investment rate of return in agricultural productions will be accessible through IT-based systems).

- Mosaqat (investment rate of return of garden products as fruits will be accessible through IT-based systems).

- Lease (of durable goods: land, construction, machinery, and equipment... are bought by bank and is leased to others. The return of this type of contracts will be distributed by sharing.

- Credit and debit cards: Non-usuric bank can issue credit and debit cards on the bases of different accounts. The debit cardholder can receive money up to the balance of her Gharz-al- Hasana or investment accounts. Credit cardholder must benefit from having an investment account either a non-usuric loan/credit contracts such as Hebeh contract for fulfillment of her consumption needs. Since the integrity of information systems is the foundation of non-usuric banking, therefore, this integrated system by preserves and controls the details of customers information in real-time by its CRM system. So every customer on the bases of their credit ranking can receive credit line in the framework of non-usuric contracts such as Mosharekeh and Modaraba through different delivery channels. Customers can access the bank's information systems' interfaces through distribution channels. After authentication and authorization by surveying information of memory of chip or magnet attached on the credit cards and final checking and confirmation of integrated system the credit request of customer is send to integrated system and the system by analyzing customer credit accessibility rank automatically process her request and intelligently devotes the requested loan/credit in basis of Mosharekeh and Modaraba contracts and by use of secure protocols and connections as Virtual Private Network (VPN), cryptography algorithms, digital signature and different security filters.

\section{Foreign exchange products and services:}

Non-usuric banking integrated systems with multi-currencies capabilities must offer non-usuric types of products and services. The following foreign exchange products and services can be offered by new non-usury banking as follows:

- Foreign currency exchange as spot, forward, and swap is allowed, and options may be used by the case of non-conditioning for a discount rate. These types of products and services will be supplied by virtual markets of foreign currency exchange, such as the internet or intranet. The main objective of forward transactions in non-usuric banking is considered for risk hedging; therefore arbitrage purposes or profit arising from differences of interest rates is canceled.

- Transaction of gold, silver, and other precious metals, participation with goldsmith or silversmith without conditioning and determining the lease rate are non-usuric and usable in the non-usuric bank.

- Receipts and payments of bills in new non-usuric banking are allowed and with the existence of E-money and real-time transactions are charged with equal commission fees for every bill of different amount values in Electronic Funds Transfer (EFT). Contradiction to this problem is acceptable wherever the cost of service grows up as the amount of nominal bill's money grows up.

- Letter of Credit (LC) issuance and commercial foreign currency exchange services for import of goods and services will be done in new non-usuric banking if they are not impressed with time duration and discounting rates. Standardization of commercial, accounting, financial stability standards, and practices have been initiated by international organizations as Basel Committee, AAOIFI, IFSB, IMF, WB, Financial Stability Forum (FSF) and International Chamber of Commerce (ICC). For example, ICC has published uniform rules of Electronic Uniform Customer and Practice for the letter of credit (EUCP), Uniform Customer and Practice for letters of credit (UCP), Uniform Rules for Collections (URC), Uniform Rules for Demand Guarantees (URDG), International Standard Banking Practice (ISBP). The non-usuric bank can also use these standards and provisions in intranet and internet networks to perform her inter-banking transactions as SWIFT. Therefore, the new non-usuric bank can use these types of infrastructures which been have initiated before by other organizations.

9. Relationship between non-usuric bank and depositors:

As in NUBankCo defined by Bidabad-Harssini (2003), it has been explained that depositors are stakeholders of the bank, and the bank is looking for maximization of depositors' profit. In this solution, applying and implementing IT systems and integrity of information in all of the systems and modules of both inter-networks and outer-networks of business partners are required. These integrated systems can trace all transactions and management quality of contracts. Therefore, synchronized IT systems in company with PLS mechanism of Mosharaka and Modaraba contracts can supply sufficient guarantees to maximize depositors' profit based on 
Islamic contracts. Thus participating in economic activities and stakeholder being of depositors is not only restrictive, but even banks could produce and supply different credit products based on Islamic contracts. This solution will be compatible with commercial regulations framework around the world.

In this solution, depositors can request products and services of the non-usuric bank. Non-usuric banking products in deposit category are Gharz-al-Hasana and investment accounts. There is not a distinguished difference between conventional non-usuric banking and new non-usuric banking regarding Gharz-al- Hasana accounts. New non-usuric banking in relation to investment accounts can do as the following ways:

I0. Establishing of stock exchange agency company and customer portfolio proportional to the amount of their deposits:

In this way, stock exchange agency companies will invest money resources of customers in financial markets, and the portfolio of each customer is specified, and encrypted certificate of deposit is sent to the customer through digital channels. To increase security, digital certificate authorities confirm issued certifications. The customer will decrypt the received certificate of deposit and reconfirm it by a digital signature and acknowledge the certified certificate of deposit to the bank. Bank can sell the shares of the customer and pay her principle and its profit to the customer through the CRM system. It should be noted that proprietorship of securities and valuable documents may be encountered as non-usuric bank assets and be located in the customer portfolio in integrated systems. For hedging market risk and losses, it is possible to insure deposits in systemic connectivity with insurance companies.

As it is obvious from the following figure, the Conceptual Architecture Model of new non-usuric banking is organized under broad headings of Foundation, Product-Services, and Customers and also External Interfaces. IT systems (including: BPR, ERP, CRM, SCM, MEX, HRM, WFM), Transformation management (including: Knowledge management, Standardization, Analytics/ business intelligent, Risk management, Business rules engine, Fraud management, Process improvement), System security policy (including: Auditing, Network connectivity, Access control, Documentation, Object Reuse, Protection domain, Identification \& Authentication, Penetration testing) are categorized as Foundations. Customers (including Government, Enterprises, people), products (including Investment deposit, Gharz-al- Hasana deposit), Services (including Foreign currency exchange, Other services) are categorized in Product-Services and Customers. The external interface is one of the most important components of non-usuric core banking which will be vital for new non-usuric banking to access data information resources which produce information in outer-networks and they are very important for the fulfillment of PLS mechanism. Data producer and information resources may include central bank, government, SWIFT, business partners, investors, stock exchange agencies, insurance companies, agricultural products exchange agencies, and other exchange markets information generators. 
Conceptual Architecture Model

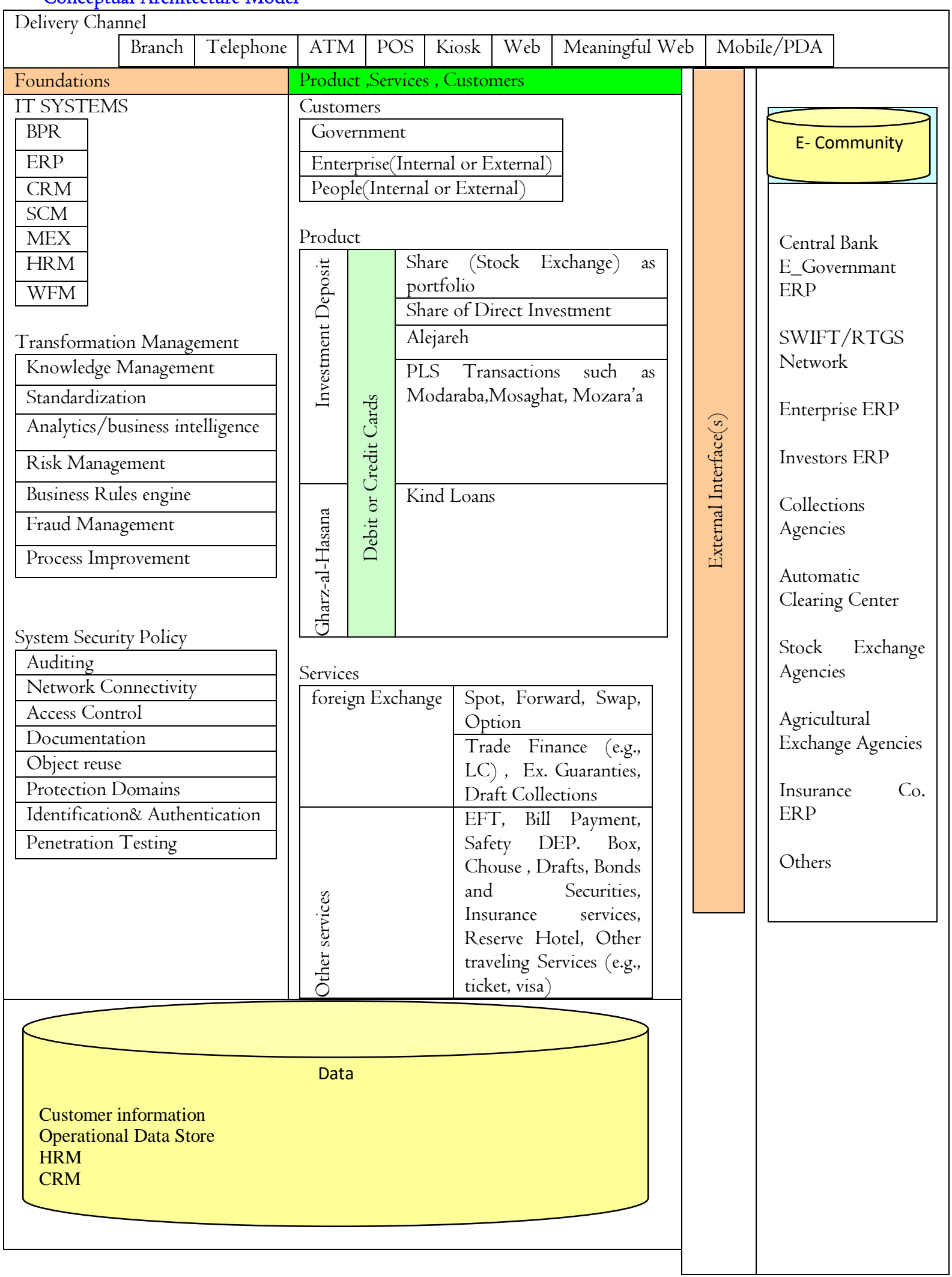




\section{Direct investment by investment company belonging to the non-usury bank:}

Non-usury bank can accomplish direct investment by establishing investment companies. Projects durations and their yields scheduling should be suitable with bank's liquidity risk to cover principle and its return of investment of depositors. The Investment Company of the non-usuric bank by evaluating projects makes necessary provisions to invest or participate in investment projects. Therefore, it is necessary that Investment Company forecasts the duration of investments and their returns and should manage risks of projects by the assistance of insurance companies. Investment Company introduces and proposes her securities and shares to customers and depositors. Customers by investing through purchasing Investment Company's shares can monitor the physical and financial and managerial progress of projects by CRM system. In the case of customer's request to end the partnership by transferring the property of Investment Company's security to others, the Investment Company buy the security through an intermediate account and sell it to others. The operational process is similar to the previous alternative.

The connection of Non-usury bank with ERP system and investors:

In this alternative, the existence of standards among information system architectures and the existence of external interfaces and gateways features in integrated systems will cause suitable infrastructures for initiating connectivity capability among ERP systems of investors, business partners and banks. In this method, the bank provides fiscal resources for investors and business partners and inform investment return conditions to depositors and customers so if they have a tendency to invest then the bank will go through automatic Mosharaka and Modaraba contracts by them. Non-usury bank considers and monitors all transactions by Real Time Gross Settlement (RTGS) systems, and estimates project progress trend, investment return, and expenditures by applying WFM systems. Therefore investment profit or loss will be shared among depositors, business partners by the proportion of their shares.

\section{Gharz-al- Hasana loans (Consumption loans ) in non-usury banking:}

Gharz-al- Hasana in the jurisprudential terminology as explained by Bidabad and Harsini (2003) ${ }^{13}$ is the transfer of some properties to a person or leave it without receiving an equivalent property. Since governments should fulfill the needs of needy peoples and make provision to access minimum livelihood condition for them, therefore they should collect money resources from tax and duties -or in Islamic countries from tithes (Zakat) for financing peoples' minimum livelihood. Thus attentive to strategic purposes of an economic enterprise which is profit maximization indeed it will be incompatible with the generosity of money for free and couldn't be expected from economic enterprise even non-usuric to accept responsibility of social security affairs.

Loan requirement for fundamental needs could be as marriage expenditures, marriage provisions, therapy of diseases expenditures, building maintenance repayment cost, educational allowances, building establishment allowances for villagers, etc. Therefore applying the loan terminology for these cases is not justified, because same pointed, Gharz-al- Hasana loan is a money payment to needy as free and without return.

If new non-usuric banking wants to supply these types of products to customers, then the bank could provide some Islamic framework such as Hebeh contract and collects the necessary resources from the following ways:

- The government can pay money to the poor in accomplishing her social security affairs and thus supply her own money resources allotments to consumption loans applicants by delivery channels of banks as Hebeh contracts.

- Non-usury bank can deliver Gharz-al- Hasana deposits for the fulfillment of consumption loan applicants (if the criterion of free loan is removed).

- Hebeh contract may be applied as outsourcing, so depositors can give their money resources in trust to the bank and then introduce persons who are needy and eligible to receive consumption loans. So, they use these resources and loaner repay its installments without surpluses. The non-usuric bank can collect commission fees according to contract context from one or two sides of the transaction for her intermediary services between depositors and loaner.

\section{Transformation Management (TM)}

I3 Bidabad and Harsini (2003), Non-Usury Bank Corporation and contemporary usury and non-usury banking operations. Proceeding of the $3^{\text {rd }}$ bi-annual Islamic economics conference (Islamic economic theory and Iran's economy), pp. I93-224, Economic Research Institute, Tarbiat Modares University, Tehran, Iran, 24-25 December 2003. http://www.geocities.com/bijan_bidabad/sherkat6.htm 
TM plays an important role in applying new IT and ICT based systems and technologies and introducing new products and services in new non-usuric banking. It also may link to Business Process Reengineering system (BPR).

\section{I4. Real Time Gross Settlement (RTGS)}

Another important component for executing and implementing of new non-usuric banking is settlement process system because the fulfillment of new non-usuric banking will require the establishment of integrated and interactive systems among depositors as stakeholders, bank and business partners, loaners, investors and insurance companies and other related agents. Distribution of profit is a complex process in Mosharaka and Modaraba contracts which involve integrated systems supporting multi-currencies and WFM systems in different layers. Interactive and integrated capabilities and the existence of standards of information will initiate connectivity capability among other intranet systems like SWIFT, central bank as an administrator of Automatic Clearing House $(\mathrm{ACH})$ and RTGS with other internal or external banking interfaces. The external interfaces should be independent in the platform and compatible with Windows family, Unix, Linux operation systems. RTGS system monitors and manages daily liquidity risk both in bank and customer levels. RTGS should possess information resource integrity and as a module of the plan should be able to perform End-to-End processing in a way that all payment transactions be managed through delivery channels as SWIFT, fax, E-mail, telephone, telex, and mobile devices. The process will be managed with minimum human interferences, minimum error, high-security aspects, and confirmation acknowledgments. Integrated information system properties as payment order message processing and tracing capability, transaction auditing will be done by WFM. Other properties of this system are as follow:

- Fault-tolerant operations including remote disaster recovery and comprehensive encryption security of payment messages and optional smartcard workstations and user authentication.

- WFM tools for scheduling, routing, and optimized method of payment.

- Automated balance checking and confirmed statement delivery to customers and business partners by use of SWIFT, fax, E-mail, and other distribution channels.

15. Designing a prototype SQL Server database in new non-usuric banking

- To design and implement IT systems as BPR, ERP, CRM, SCM, MEX, HRM and WFM Datacenter operating systems and client/server databases and applications are necessary. The most important operating systems are: Windows server data center, Sun OS, UNIX, Linux, and important client/server capability databases are: Oracle and MS SQL Server.

- Data Integrity (DI) is the first step of designing integrated systems databases and refers to the consistency and accuracy of data stored in the database. For designing an integrated system, there are four types of DI: domain integrity, entity integrity, referential integrity, and user-defined integrity.
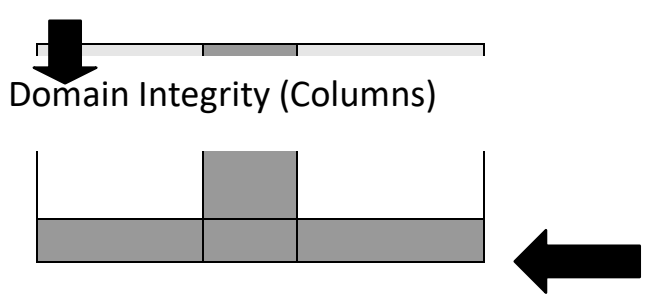

Entity Integrity (Rows)

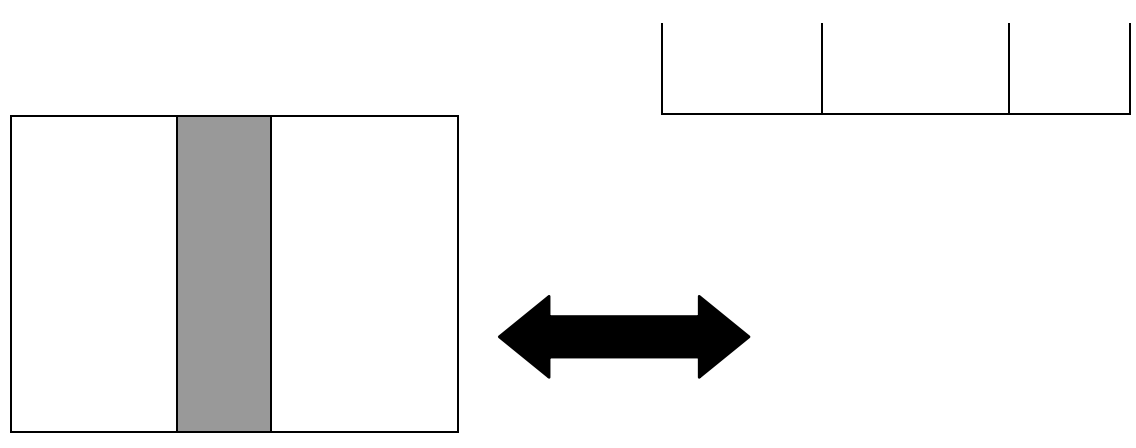

This figure shows the connectivity of

Referential Integrity (between tables) 
- Domain Integrity: Domain (or column) integrity specifies the set of data values limitations that are valid for the field (column).

- Entity Integrity: Entity integrity requires that all rows in a table have a unique identifier, known as the primary key value.

- Referential | Integrity: Referential integrity ensures that the relationship between the primary key (in a referenced table) and the foreign key (in each of the referencing tables) is always maintained. This relationship will cause the following consequences:

- A row in a referenced table cannot be deleted, nor can the primary key be changed, if a foreign key refers to the row.

- A row cannot be added to a referencing table if the foreign key does not match the primary key of an existing row in the referenced table.

- User-Defined Integrity: This type of integrity ensures the security of business and organizational rules that do not fall into one of the other integrity categories. Constraints ${ }^{14}$, stored procedures ${ }^{15}$, and triggers ${ }^{16}$ are available for enforcing user-defined integrity.

Therefore, by using integration procedures in databases, the main customer table includes customer's specifications such as account number as the primary key field. Primary key fields and foreign key connectivity in all of the data tables in internetwork and outer-network make integrated information bases. Therefore all customers' transactions are traced in the E-community -even around the world- using ERP system.

\section{I6. IT in non-usuric banking in comparison with usuric banking}

Fulfillment of IT-based banking needs suitable infrastructures. These infrastructures do not only include technical and telecommunications but also contain cultural, educational, and also legal aspects. Although the necessity of suitable infrastructures for both non-usuric and usuric banking are the same, IT role in non-usuric banking is vital. Initiation an integrated information community, investing on real economy sectors, financial stability according to FSF standards in financial markets, coordination and interaction of systems for transferring information and use of shared hardware and software resources as an actuality for implementing new non-usuric banking are unavoidable. Therefore, applying and implementing IT-based systems in non-usuric banking not only will initiate opportunities as same as other IT-based businesses but also will establish PLS mechanism nature in the society. For example, initiating an ERP system for the huge community not only will cause the decline of overhead cost but also all people in different organizations who need information will be able to access to precise and up to date information. Therefore, if the data warehouse of Management Information System (MIS) were managed or supervised by a unique integrated system, then the actual investment return of customer portfolio is completely traced. Consequently, the effectiveness and transparency of economic system certainly increase. Implementing and applying integrated IT systems (BPR, ERP, CRM, SCM, MEX, HRM, WFM) lets architectural feasibility for initiating comprehensive integrated system by connecting information resources of the bank, depositors, insurance companies, investors, business partners and also capital market especially through establishing NUBankCo.

IT systems accompanying with complement information systems can connect non-usuric banking information resources as rings of a chain. Therefore depositors as stakeholders of a company will be investment patron who is an extreme purpose of nonusuric banking. Interaction among non-usuric bank and business partners can be done in different ways. The following tables summarize IT based non-usuric banking in comparison with conventional non-usuric banking:

\footnotetext{
${ }^{14}$ Constraints are a standard method of enforcing data integrity. Microsoft ${ }^{\circledR}$ SQL Server ${ }^{\mathrm{TM}} 2000$ automatically enforces the integrity of a database. See: Microsoft SQL Server.2000, Microsoft Corporation press, 2000

I5 Stored procedures can manage database and display information. Stored procedures are a precompiled collection of SQL statements and optional control-of-flow statements stored under a name and processed as a unit. See: Microsoft SQL Server.2000, Microsoft Corporation press, 2000.

I6 A Trigger is a special type of stored procedure that is not called directly by a user. When a Trigger is created, it is defined to execute when a specific type of data modification is made against a specific table or column. See: Microsoft SQL Server.2000, Microsoft Corporation press, 2000.
} 


\begin{tabular}{|c|c|c|}
\hline New non-usuric banking (IT based) & Conventional non-usuric banking & \\
\hline $\begin{array}{l}\text { Possibility to initiate systemic connectivity and transparent } \\
\text { relationship between depositors and investors. } \\
\text { Possibility to establish customers' shares portfolio based on } \\
\text { their deposit amount. } \\
\text { There are not different rates of investment return on the } \\
\text { basis of different time deposits. } \\
\text { All Stakeholders, bank, business partners and all other } \\
\text { partners use the bank's productivity. } \\
\text { Applicability of every contract according to PLS } \\
\text { mechanism confirming non-usuric criteria. } \\
\text { Increasing competition for investment in the real economy } \\
\text { because there is a WFM system for accounting, auditing } \\
\text { and tracing. } \\
\text { Agreement on execution and operational processes of } \\
\text { transactions. }\end{array}$ & $\begin{array}{l}\text { Impossibility to initiate systemic connectivity and } \\
\text { transparent relationship between depositors and } \\
\text { investors. } \\
\text { Impossibility to establish customers' shares portfolio on } \\
\text { the basis of their deposit amount. } \\
\text { Determining different rates of returns (interest rates) for } \\
\text { different time deposits. } \\
\text { Maximization of the bank's profit function via widening } \\
\text { banking spread (difference if the loan and deposit } \\
\text { interest rates). } \\
\text { Applying unrestricted Modaraba or Kefaleh contracts } \\
\text { and determining the minimum investment return rate. } \\
\text { Unlawful and immoral competition among banks for } \\
\text { determining the rate of return to increase shareholders' } \\
\text { profit. } \\
\text { Disagreement on execution and operational processes of } \\
\text { transactions. }\end{array}$ & 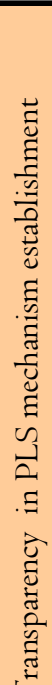 \\
\hline $\begin{array}{l}\text { Stability in financial markets because of stable money } \\
\text { markets and prevailing FSF standards. } \\
\text { Standardization in operational, supervising and } \\
\text { management process and unique practices. } \\
\text { Lower markup prices of banking products and services. } \\
\text { Access to international markets because of compatibility } \\
\text { and integrity capabilities. } \\
\text { Satisfaction and tranquility of customers will be a result of } \\
\text { products and services quality. } \\
\text { Deletion of unofficial financial markets and usury in the } \\
\text { society. } \\
\text { Decrease of investment cost and increase of productions in } \\
\text { the society because of lowering cost of capital rent in } \\
\text { resource mobilization. } \\
\text { Dampening money laundering activities because of effective } \\
\text { supervisory on processes and tracing of transactions. } \\
\text { Depositors will derive actual investment returns of } \\
\text { economic activities. } \\
\text { Expansion and development of social justice in the society } \\
\text { through better allocation of resources. }\end{array}$ & $\begin{array}{l}\text { Fluctuations in financial markets resulting from money } \\
\text { markets fluctuations. } \\
\text { Varieties of methods and non-unique practices and } \\
\text { standards. } \\
\text { Higher markup prices of banking products and services. } \\
\text { Less ability to possessing global market share and } \\
\text { working with restricted market and customers. } \\
\text { The dissatisfaction of customers because of paperwork } \\
\text { and bureaucratic procedures concerning the supply of } \\
\text { products and services. } \\
\text { Expansion of unofficial financial markets and usury in } \\
\text { the society. } \\
\text { Increase of investment cost and decline of productions } \\
\text { in the society because of the growing cost of capital rent } \\
\text { in resource mobilization. } \\
\text { Expansion of money laundering activities because of } \\
\text { ineffective supervisory on processes and tracing of } \\
\text { transactions. } \\
\text { Depositors will be deprived of actual investment returns } \\
\text { of economic activities. } \\
\text { Expanding of unfair allocation of resources and } \\
\text { wealth in the society. }\end{array}$ & 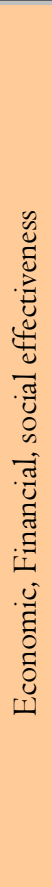 \\
\hline
\end{tabular}




\begin{tabular}{|c|c|c|}
\hline New non-usuric banking (IT based) & Conventional non-usuric banking & \\
\hline $\begin{array}{l}\text { Less operational risk. } \\
\text { Continual accounting and auditing process capabilities on } \\
\text { Moshreka or Modaraba contraction by use of the WFM } \\
\text { system. } \\
\text { More confident forecasts of the financial market variables } \\
\text { because of standardized and unique practices especifically } \\
\text { through WFM system on operational, supervising and } \\
\text { management process. } \\
\text { Supervising capability on business partners and their } \\
\text { manner of management. } \\
\text { Ability to present reliable documents and monitoring } \\
\text { projects conditions and convincing customers in case of } \\
\text { projects' loss. } \\
\text { Lower liquidity risk. } \\
\text { Higher ability to assess, forecast, and scheduling the bank's } \\
\text { liquidity requirement because of accuracy and accessibility } \\
\text { information. } \\
\text { Full use of resources and ineffectiveness of hearsays to } \\
\text { withdraw deposits and bankruptcy because of liquidity risk. } \\
\text { Transparency of financial sound situation of bank and } \\
\text { accessible actual capital adequacy ratio for embracing } \\
\text { liabilities and the ability for international non-usuric inter- } \\
\text { banks financing. } \\
\text { The attraction of customers and expansion of market } \\
\text { because of sound financial stability resulting from the } \\
\text { enjoyment of customers from the real economy yeilds. } \\
\text { Lower market risk. } \\
\text { Stability of price of goods in futures. } \\
\text { Stability of inflation rate and preservation of customer } \\
\text { financial position. } \\
\text { Less morality risk: symmetric information in Mosharaka or } \\
\text { Modaraba contracts and monitor capability for tracing } \\
\text { investment and fulfillment of PLS mechanism. }\end{array}$ & $\begin{array}{l}\text { I- Higher operational risk. } \\
\text { 2- The incapability of continual accounting and auditing } \\
\text { process. } \\
\text { 3- Less confident forecasts of the financial market } \\
\text { variables because of varieties of practices. } \\
\text { 4- Incapability to supervise on business partners and } \\
\text { Mozareb (investment operator) and lack of ability to } \\
\text { survey their managerial capabilities and qualities before } \\
\text { project maturity. } \\
\text { 5- Inability to present acceptable documents and reasons } \\
\text { for legal claiming in the court based upon to be a partner } \\
\text { of depositors in loss conditions for confirmation of } \\
\text { Moshreka or Modaraba contracts. } \\
\text { 6- Higher liquidity risk. } \\
\text { 7- Less ability to assess, forecast, and scheduling the } \\
\text { bank's liquidity requirement. } \\
\text { 8- Useless of partial amount of resources for risk } \\
\text { management and decline of investment returns hedging. } \\
\text { 9- Unavailable modern monetary, inter-banks, stock } \\
\text { exchange, derivative markets and inaccessible precise } \\
\text { banking information for international financing. } \\
\text { Missing customers because of higher loss probability in } \\
\text { Mosharaka or Modaraba contracts. } \\
\text { II- Higher market risk. } \\
\text { I2- Fluctuations in goods prices in the futures in Salam } \\
\text { or Forward (Albeyea Salaf) contracts. } \\
\text { I3- Higher inflation rate arising from financial markets' } \\
\text { fluctuations. } \\
\text { I4- Morality risk: Asymmetric information in } \\
\text { unrestricted Modaraba }{ }^{17} \text { may cause expansion of } \\
\text { immoral activities for increasing the bank's profit. }\end{array}$ & 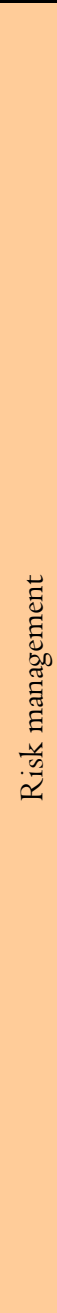 \\
\hline
\end{tabular}

\section{I7. Conclusions and policy recommendations:}

In spite of various attempts of Islamic and non-Islamic countries for executing non-usuric banking, there is no important achievement in the general understanding of non-usuric transactions and their standards. One of the important proposals to fulfill non-usuric banking is "NUBankCo". Based on the proposal, depositors are stakeholders of bank and bank on the bases of depositors' money resources that indeed will be the founder of the enterprise (bank) should maximize depositors' profit. Investment returns and in general bank's revenue will be divided among stakeholders (depositors) in the proportion of their shares (i.e., amount and duration of deposit relative to the total amount of deposits and their durations). Operational, supervising, managerial processes and risk management will be very transparent in this bank in comparison with conventional banking. Fulfillment of transparency in NUBankCo with access to updated real and precise information and supervision over transactions and manner of projects' management will decrease operational risk and will maximize depositors' profit.

${ }_{17}$ Unrestricted Modaraba: In this type of contracts depositors agree with bank that according to bank's direction, money resources of customers be invested and depositors will participate in investment returns. 
Supply of products and services based on IT systems and standardization in order to compete with other banks and globalization is unavoidable. But the fulfillment of PLS mechanism and establishment of NUBankCo will be more realistic and more effective by applying IT-based systems as BPR, ERP, CRM, SCM, MES, HRM, WFM, K-M. Because all these systems possess integrity characteristics and use a unique data warehouse, and they are components of a unique system and are responsible for handling specific functions. This system not only will record and manage inter-network processes but also embrace all financial and non-financial transactions of business partners as interactions of multi-layers and multi-parties. This capability requires external interfacing, gateway, and RTGS with security characteristics of integrated information. Therefore, access and supervising detailed information and processes exist. In other words, by applying and implementing IT-based systems, it will become possible to embrace all information requirements of NUBankCo to fulfill real PLS mechanism.

In this bank, similar to other banking systems, delivery channels include digital and non-digital channels. Executing new nonusuric banking will initiate new opportunities in different aspects of globalization, market expansion, competition capability with other conventional banks in order to safeguarding depositors' profits and participating them in actual economy yields, and provision of social justice, lubricating complicated interactions between banks in Islamic and non-Islamic countries and decreasing immorality risks and money laundering etc. Standardization in all processes and practices of operational, supervising, and managerial aspects should be done by an independent organization to fulfill this type of banking.

\section{References \\ (13) (تحليل فقهي- اقتصادي ربا در وامهاي مصرفي و سرمايهكاري و كاستيهاي فقه متداول در كثف احكام}

http://www.geocities.com/bijan_bidabad/reba7.htm

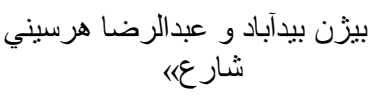

http://www.geocities.com/bijan_bidabad/sherkat6.htm

الهياري فرد، محمود (I384)، خدمات بانكداري الكترونيك و نياز هاي اجر ائي آن در مقايسه تطبيقي هزينه عملياتي خدمات مختلف بانكيءيزو هشكده

The Localization Industry Standards Association (Lisa), http://www.lisa.org يولي ويانكي، بانكا مركزي.

Microlink Banking Solutions release, http://www.microlink.com

Riffat,Ahmad Abdel Karim and Simon Rcher "Islamic Finance : Innovation and Growth", Euromoney, 2003

Errico, Luca \& V.Sundararajan, "Management Risk Workshop in Islamic Financial System ", paper," Islamic banking Conference in Iran " 2002, http://www.fundtech.com

Dadang Muljawan \& Humayon A. Dar \& Maximilian J.B. Hall" A Capital Adequacy Framework for Islamic Banks: The Need to Reconcile Depositors' Risk Aversion With Managers' Risk Taking",paper,2003

"Bahrain Monetary Agency Issues New Islamic Banking Regulations", VOL. XLV No 5, 4 February 2002, http://www.mees.com/postedarticles/finance/babrain/a45n05b04.htm

"Adapting to a Rapidly Changing Regulatory \& Financial Environment",Bahrain Monetary Agency press, 9 Feb 2003

http://www.aaoifi.com/main/contact.html

http://www.aaoifi.com/organization/orgstructure3.html\#CallSiteMap

SQL Server.2000, Microsoft Corporation, Washington, 2000

\section{Copyrights}

Copyright for this article is retained by the author(s), with first publication rights granted to the journal. This is an open-access article distributed under the terms and conditions of the Creative Commons Attribution license (http://creativecommons.org/licenses/by/4.0/) 